\title{
What explains small- and medium-sized apparel retailers' international market involvement? An application of Uppsala model
}

\author{
Hyeon Jeong $\mathrm{Cho}^{{ }^{*}}$ and Byoungho $\mathrm{Jin}^{2}$
}

*Correspondence:

hjcho@semo.edu

${ }^{1}$ Department of Human

Environmental Studies,

Southeast Missouri State

University, One University

Plaza, Mail Stop 5750, Cape

Girardeau, MO 63701, USA

Full list of author information

is available at the end of the article

\begin{abstract}
The purpose of this study is to investigate U.S. small- and medium-sized apparel retailers' international expansion by proposing a theoretical framework that incorporates the antecedents of small- and medium-sized apparel retail firms' international market involvement. Data were collected via a self-administered questionnaire completed by apparel retailers nationwide. A total of 76 usable questionnaires were collected based on Dillman et al. (Internet, mail, and mixed-mode surveys: The tailored design method, 2009) Mail Survey technique. The results indicate that small- and medium-sized apparel retailers who have more foreign networks are likely to have foreign market knowledge. Firm age and market knowledge were found to influence a firm's international market involvement. The results further reveal that market knowledge mediates the relationship between foreign networking and international market involvement. This study contributes to the growing knowledge base about small- and medium-sized retailers' international expansion in the apparel industry.
\end{abstract}

\section{Introduction}

The US apparel retail sector has faced fierce competition and saturated markets as evidenced by a severe decline in consumption and retail store closures (U.S. Bureau of Economic Analysis 2011). Annual US apparel and footwear sales are expected to shrink by $\$ 7$ billion, while sales in leisure and recreation increase $\$ 412$ billion between 2010 and 2020 (Euromonitor 2013). Due to long struggling, Gap announced to close 140 North American stores by early 2016 (Kapner 2015). In 2015, the struggling young-apparel retailer Wet Seal is projected to close 338 stores, representing about two-thirds of its stores (The Associated Press 2015, January 7). The shrinking expenditures on clothing and footwear in the US retail markets have forced clothing retail stores to close. To extend the lifespan of the declining US apparel retailing industry, therefore, many US apparel retailers have expanded their businesses to international markets.

Most US apparel companies are small- and medium-sized firms (SMEs), defined as those with fewer than 500 employees in the US market (U.S. Small Business Administration 2013). Firm size is by no means a significant impediment to internationalization (Molla-Descals et al. 2011) and many SME retail companies have succeeded in global markets (Hutchinson et al. 2006). Previous studies, however, have focused mostly on

(C) 2015 Cho and Jin. This article is distributed under the terms of the Creative Commons Attribution 4.0 International License (http://creativecommons.org/licenses/by/4.0/), which permits unrestricted use, distribution, and reproduction in any medium, provided you give appropriate credit to the original author(s) and the source, provide a link to the Creative Commons license, and indicate if changes were made. 
large retailers' international expansion (e.g., Vida et al. 2000), with a very limited number of studies of SME retailers' international expansion. Considering the number of SME firms and their contribution to the economy (Stoll and Ha-Brookshire 2012), US SME apparel retailers' internationalization needs to be understood in order to identify their current international activities and help them establish effective international strategies.

As the tradition behavioral learning theory, the Uppsala model emphasizes the role of organizational knowledge in the internationalization process that has received much attention across the large manufacturing sector and the small export sector (e.g., Autio et al. 2000). The Uppsala model, however, has been criticized because its two explanatory factors may be insufficient to understand international market involvement (Forsgren 2002). Moreover, the notion of emphasis on experiential knowledge is too deterministic because a firm can also learn from indirect learning sources (e.g., observation, network) (Forsgren 2002). Considering that small retail firms have limited financial resources and experience, their market knowledge sources might be different from those of large firms. Nevertheless, few studies have examined whether possible indirect sources influence market knowledge. To fill this gap, there is a need for a more in-depth investigation of both direct and indirect learning sources to build foreign market knowledge and the antecedents that may influence the international market involvement of SME apparel retailers.

The purpose of this study is to investigate US SME apparel retailers' internationalization by proposing a theoretical framework that expands the Uppsala model and incorporates factors related to their international market involvement. Based on the Uppsala model's explanatory variables, this study includes firm age, product uniqueness, and domestic growth opportunity as international market involvement antecedents. The expanded model also uses foreign sourcing experience and foreign networking as determinants of market knowledge. The proposed framework is empirically tested with data collected from apparel retail firms nationwide.

\section{Literature review}

\section{Internationalization theory: the Uppsala model}

The Uppsala model, also called the U-model or the internationalization process model, proposes that levels of knowledge about and commitment to foreign markets influence decisions related to internationalization and business activities (Johanson and Wiedersheim-Paul 1975; Johanson and Vahlne 1977). Psychic distance, the degree of cultural and social difference between the home country and the host country, can disturb a firm's understanding of a foreign market (Johanson and Vahlne 1977). The assumption of the Uppsala model is that lack of knowledge from the psychic distance is a major obstacle to international operations, so firms gradually increase their level of involvement to minimize the risk and uncertainty (Johanson and Vahlne 1977).

Despite its significant contributions to internationalization research, the Uppsala model has been criticized for being too deterministic and simplistic (Forsgren 2002). The first challenge is that the Uppsala model puts too much emphasis on experiential knowledge or "learning by doing" on knowledge as obtained only through ongoing activities. Apparel retailers can build their foreign market knowledge through both direct learning behaviors, such as foreign sourcing activities, and indirectly, such as through foreign 
networking. While the weakness of emphasizing only direct learning has been discussed (Forsgren 2002; Oviatt and McDougall 1994) and Ellis and Pecotich (2001) reported learning from networking or observations, few studies have examined whether possible indirect sources influence market knowledge. To fill this gap, SME apparel retailers' knowledge sources are incorporated into the model.

The Uppsala model uses only two factors (i.e., market knowledge, market commitment), which may be insufficient to explain international expansion (Forsgren 2002). There is a compelling need for a more in-depth investigation of the firm-, retail-, and market-specific antecedents that may influence the international market involvement of SME apparel retailers. This study posits that the Uppsala model can better explain current international market involvement by incorporating antecedents related to SME apparel retail firms and current domestic apparel markets. In this study, firm age, product uniqueness, and domestic growth opportunity are selected as key influences. Firm age can affect international market involvement (Chen and Sternquist 1995). Unlike manufacturing firms, apparel retailers differentiate themselves largely through intangible assets (Quinn and Doherty 2000); thus, their international market involvement may depend on the product's being sufficiently unique. Another antecedent, firms' perceived domestic growth opportunities, can influence their international market involvement because firms that perceive limited domestic growth are more likely to expand into international markets (Lopez and Fan 2009).

As shown in Fig. 1, the study proposes a conceptual model that incorporates two sources of market knowledge (foreign sourcing experience and foreign networking) and firm-specific (firm age, market knowledge, and market commitment), retail-specific (product uniqueness), and market-specific (domestic growth opportunity) factors related to apparel retailers' international market involvement. We examine seven hypotheses based on the relationships of these factors. The basic premise of the proposed model is that both direct and indirect sources of learning influence the level of foreign market knowledge: the firm-, retail-, and market-specific factors determine the international market involvement, and market knowledge mediates the relationship between sources of market knowledge and international market involvement.

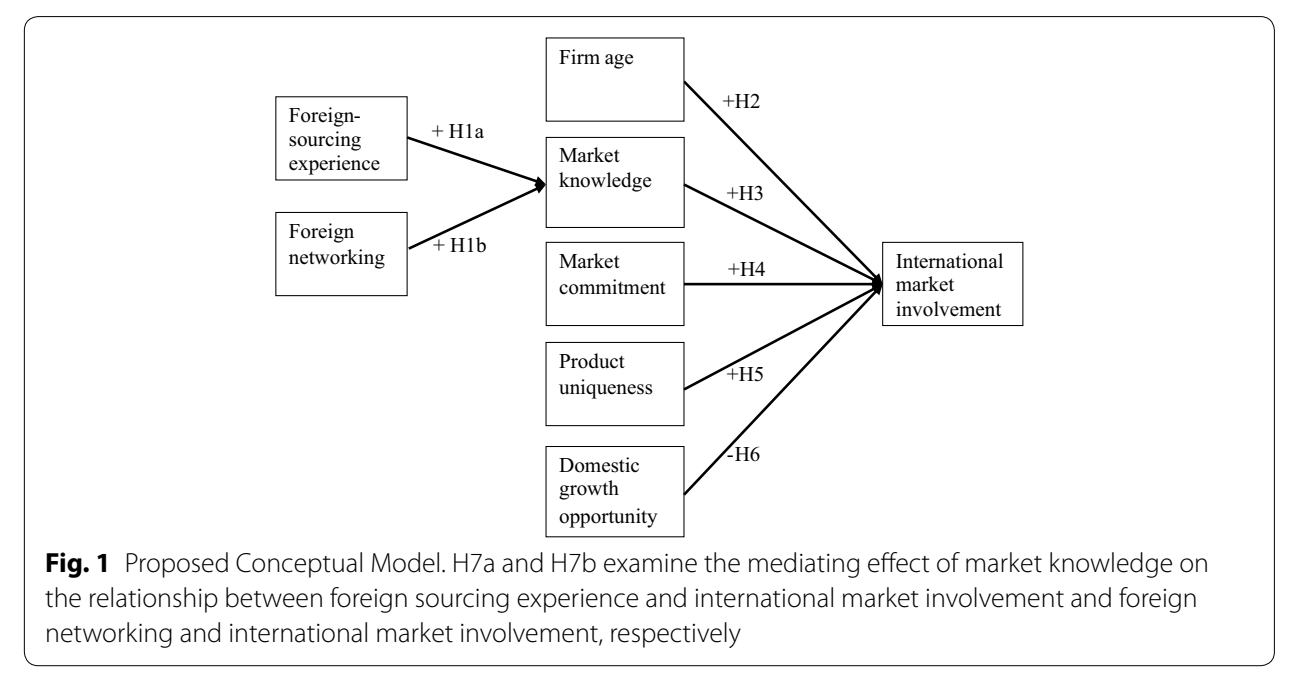




\section{Antecedents of market knowledge}

Foreign sourcing provides the opportunity to gain detailed local knowledge at the retail level (Palmer and Quinn 2005). Because producing apparel goods requires significant labor, apparel firms in developed countries have turned to overseas sourcing for products sold in domestic markets. This overseas experience has become their primary method of learning about international markets. In a case study by Guercini and Runfola (2010), a small Italian apparel retailer entered the Chinese market for sourcing and later opened retail stores based on its newly acquired Chinese market knowledge (e.g., local consumer behavior). During the sourcing stage, the firm learned business skills in an emerging market and the importance of social bonds, such as "guanxi," in doing business with Chinese suppliers and later applied this knowledge in its retail operations. About $97 \%$ of apparel products sold in the US are produced overseas (American Apparel \& Footwear Association 2009). The business travel that is essential for establishing and maintaining sourcing relationships results in exposure to local trends, aesthetic preferences, competitor activities, and negotiation strategies. Therefore, experiencing foreign sourcing in multiple countries helps apparel retailers gain information about international markets (e.g., consumer needs, cultural norms, languages, regulations, negotiation skills, and distribution channels). This study thus hypothesizes the following:

H1a: The greater a firm's foreign sourcing experience, the greater its market knowledge.

Many case analyses suggest that personal relationships, both formal (e.g., clients and former employees) and informal (e.g., friends and relatives), serve as instrumental tools for obtaining foreign market information by SME firms (e.g., Ellis and Pecotich 2001; Johnsen and Johnsen 1999; Prashantham 2006). From their personal relationships with suppliers and foreign agents, four small knitwear manufacturers studied by Johnsen and Johnsen (1999) obtained informal information on foreign local customers and an awareness of foreign market opportunities. Foreign networking is also important for building market knowledge. Hutchinson et al. (2006) study of three U.K. SME clothing and accessory retailers shows that the firms' founders or senior managers created strong social bonds with people they met while travelling in foreign countries, resulting in their becoming the first local distributors in two foreign markets. Based on the above, this study posits that foreign networking is an informal source of market knowledge and that increased personal relationships in foreign markets expand SME apparel retailers' opportunities to develop market knowledge. Therefore, this study hypothesizes the following:

H1b: The greater a firm's foreign networking, the greater its market knowledge.

\section{Antecedents of international market involvement}

The Uppsala model posits that before moving into international markets, firms are adequately established in their domestic market, having reduced market risks and uncertainty based on their experience (Johanson and Vahlne 1977). Traditional explanations of gradual internationalization may not apply to all sectors, such as the emerging bornglobal firms of the high-tech industry (Oviatt and McDougall 1994); high-tech firms 
tend to expand their businesses when young (Aspelund and Moen 2005; Autio et al. 2000). In contrast, retail firms may need sufficient time to build brand image and identity and increase market appeal of the company in their domestic markets before its expansion (Hutchinson et al. 2006). For example, established in 1969, Gap, Inc. opened its first international store in the UK in 1987 after 20 years of operating in the US (Gap Inc. 2015). Limited Brands Inc. (established in 1963) and J.Crew (begun in 1983) entered Canada, their first foreign market, after 44 and 28 years of operating in their domestic markets respectively (Wahba 2015; Limited Brands 2011). Comparing domestic and international retail stores, Chen and Sternquist (1995) found that international retail stores had longer histories of establishment. As retailers' competitiveness is derived from their store name, service, or product assortment, apparel retailers may follow a traditionally gradual process with a domestic orientation. Hence, the age of the firm may be important in explaining international involvement. We therefore propose the following hypothesis:

\section{H2: The older a firm, the higher the probability of international market involvement.}

The logic of the Uppsala model asserts that developing market knowledge (e.g., about regulations, norms, distribution channels, business cultures) can reduce uncertainty and perceived risks (c.f., Johanson and Wiedersheim-Paul 1975) and thus lead to engagement in international markets. For apparel retail firms, knowledge of local history, language, religion, consumer needs, cultural aesthetic tastes, and merchandise distribution are all essential for operating in foreign markets for the following reasons: (1) the color and design of apparel goods can deliver social meanings (Roach-Higgins and Eicher 1992), (2) local consumer needs and aesthetic tastes vary widely (Jin 2004), and (3) apparel items include a wide range of inventory stock (Jin 2004). Therefore, apparel firms with a high degree of knowledge of their host markets are in a better position to overcome risks and uncertainties, which in turn increases the potential for a decision to internationalize. In sum, this study postulates that market knowledge will lead to international market involvement among apparel retailers. We thus hypothesize the following:

H3: The greater a firm's market knowledge, the greater the probability of international market involvement.

Since entry costs and transaction risks in internationalization can be high, the decision is necessarily affected by managerial willingness to commit resources with a long-term view. Thus, an earlier entry might be prompted by high market commitments to tangible (e.g., financial investment) and intangible (e.g., time, information search, patience) resources (Navarro et al. 2010). Firms' commitments to international activities in turbulent markets are well documented. For instance, despite an internal crisis and war between Iran and Iraq (1982-1988), Swedish firms such as Volvo did not withdraw their businesses but maintained their market commitments due to the post-war market potential (Hadjikhani 1997). In this case, firms integrated all of their tangible and intangible commitments to their focal markets.

High foreign market commitment may assist firms in overcoming foreign market uncertainty, which may in turn lead to their internationalization. In a case study of a US and UK early-internationalized apparel firm, the ambition of one of its founders was to 
bring his firm's style and vibrancy to global consumers, resulting in seeking foreign market opportunities (Wigley et al. 2005). Therefore, this study postulates that strong market commitment to internationalization will lead to international market involvement:

H4: The greater a firm's market commitment, the higher the probability of international market involvement.

Product uniqueness contributes to retail differentiation and has been identified as a key driver of the retail industry's international expansion (Alexander 1990). Evans et al. (2008a) and Williams (1992), in investigating empirically the motives for retail internationalization, have highlighted the importance of the uniqueness of the retail offering. Treadgold (1991) found that a unique product makes entry into a foreign market much easier. In particular, product uniqueness has often been emphasized as a driver of smalland medium-sized retailers because it enables smaller firms to expand into foreign markets despite resource limitations (Hutchinson et al. 2006). Additionally, a unique product line contributes to the focus on a target market, which leads in turn to retailer confidence and differentiation for small retailers (e.g., Foscht et al. 2006). One plausible explanation is that unique features can satisfy various aesthetic preferences and local consumer needs in foreign markets. We therefore hypothesize the following:

H5: The more unique a firm's product is, the greater the probability of international market involvement.

Domestic growth opportunity may be a crucial push factor of apparel retailers' internationalization. Many studies have shown that apparel retail firms are encouraged to expand into foreign markets because of the maturity of their domestic markets (Lopez and Fan 2009; Wigley et al. 2005). Many cases support this finding. Gap's struggles in the US market have accelerated its rapid expansion across the Chinese market since its 2010 entry (Lee 2010). Similarly, limited domestic market growth opportunities led Zara to expand internationally (Lopez and Fan 2009). The entry of British children's wear retail, Adams, in Spring in the mid-1990s were attributed to imminent market saturation and increased domestic competition (Johnson and Allen 1994). Slowing domestic demand in developed countries has been found to prompt a rapid internationalization (Wigley et al. 2005). Given the weight of the empirical findings, this study posits that apparel retailers who perceive fewer domestic market growth opportunities are more likely to expand their businesses to international markets. We therefore hypothesize as follows:

H6: The smaller a firm's perceived domestic growth opportunity, the greater the probability of international market involvement.

\section{Market knowledge as a mediating factor}

Foreign sourcing experience and foreign networking drive the international market involvement through their impact on market knowledge. The sequence from foreign sourcing experience to market knowledge to international market involvement occurs because foreign sourcing is prevalent in the fashion industry (Guercini and Runfola 2010). Similarly, foreign networking can influence international market involvement via 
its impact on market knowledge. For example, Ellis and Pecotich (2001) found that social networks with former employees became tools for finding foreign business partners and building local market knowledge. Therefore, small apparel retailers' sourcing experience and foreign networking are viable sources of stock market knowledge, providing a greater opportunity to expand their businesses internationally (Alexander 1990; Guercini and Runfola 2010). This link between foreign sourcing experience and networking and international market involvement via the mediating role of market knowledge is captured in the hypotheses below:

H7a: Market knowledge will mediate the relationship between foreign sourcing experience and international market involvement.

H7b: Market knowledge will mediate the relationship between foreign networking and international market involvement.

\section{Method}

\section{Sample and data collection}

The proposed theoretical model was tested using data collected from a survey of US SME apparel retailers. The US SME apparel retailers were selected as an appropriate same frame because internationalization has been emphasized as a vital means of survival and growth for the US apparel retail industry including small and medium sized firms; thus, understanding the factors influencing international market entry is important in encouraging US apparel retailers to decide on internationalization. Sample firms met the following criteria: (1) the firm has less than 500 employees; (2) its primary activity is selling apparel and related accessory goods through brick-and-mortar retailers; (3) it is classified as Standard Industrial Classification (SIC) code 56 (Clothing and accessories store); and (4) it is at least 6 years old, the first 6 years being regarded as the crucial period when most firms' survival is determined (Oviatt and McDougall 1994).

A total of 1320 firms meeting the four criteria were selected from the Dun and Bradstreet database as the study's initial sample frame. After excluding firms for a variety of reasons (e.g., a no-survey policy, not reachable), the adjusted sample was 1139. A self-administered questionnaire was mailed to top management (e.g., CEO, vice president). Following Dillman et al. (2009) survey technique, the following steps were taken: a pre-notification postcard, an initial questionnaire, a reminder postcard, a second questionnaire, and final phone and email contacts. As the first survey package resulted in a low response rate, phone calls and emails were made during the second mailing period to encourage the participation of firms who had misplaced, lost, not received, or not responded to the first mailing. By the end of the data collection, the final useable questionnaires totaled 76, representing a response rate of $6.67 \%$. A series of $t$ tests was performed to measure the non-response bias by comparing questionnaires received after the first mailing and after the second mailing. No statistical evidence of non-response bias, such as annual sales volume and number of domestic retail stores, was identified in the firms' demographic characteristics. 


\section{Measures}

\section{International market involvement}

The measurements used in this study were developed through reviews of prior studies. International market involvement is defined as the various international business activities that generate sales from foreign markets (Alexander 1990; Vida et al. 2000). Based on this definition, this study uses foreign sales as evidence of international market involvement (e.g., Alexander 1990; Hutchinson et al. 2006). International market involvement, a dichotomous variable, was operationalized as current international sales (e.g., Vida et al. 2000): retailers without international sales were coded "0" whereas retailers with international sales were coded " 1 ".

\section{Antecedents of market knowledge}

To measure foreign sourcing experience, two continuous items (i.e., the number of years the firm has operated with foreign sourcing and the number of countries in which the sourcing activities occur) were adopted from Evans et al. (2008b). Foreign-sourcing experience was subjected to a principal component analysis in order to produce a factor score. Foreign networking was measured using six items adopted from Jin and Jung (2013). Respondents were asked to assess the strength of personal relationships with people in foreign countries, including former employers/employees, existing clients, business associates, relatives, friends, and former classmates using an interval scale ranging from "very weak" (1) to "very strong" (7), with a "none" option (0).

\section{Antecedents of international market involvement}

As a continuous variable, firm age was operationalized as the number of years the firm has been in existence (e.g., Rothaermel et al. 2006). A firm's foreign market knowledge was measured through nine items drawn from Hadley and Wilson (2003) to manifest two dimensions: foreign institutional knowledge and foreign business knowledge. Foreign institutional knowledge was determined using four items, concerning the firm's foreign language, foreign business laws, foreign business norms, and foreign business standards, with a Cronbach's alpha of 0.86. Foreign business knowledge was derived from the five items: foreign competitors, foreign distribution channels, business contacts in foreign markets, foreign consumer needs and preference, and foreign sales developments. This dimension had a Cronbach's alpha of 0.85 . To reflect the retail industry, foreign business standards and foreign sales development items were modified into foreign business regulations in retail industry and effective marketing in foreign markets. Nine items were measured by a 7-point Likert-type scale with endpoints defined by "very low" (1) and "very high" (7). Three market commitment items with a Cronbach's alpha of 0.915 were adopted from Navarro et al. (2010): "The level of time and effort our firm's management commits to international activity is," "The level of financial resources committed to the international activity is," and "The level of human resources committed to the international activity is" ( $1=$ "very low" and 7 = "very high").

The scale for product uniqueness was drawn from Aspelund and Moen's (2005). Statements included "Our products are unique in terms of designs and features," "Our products are innovative and creative to meet consumer demands," "Our products meet demands for special target segments," and "Our customers visit our store to buy unique 
and specialized products". These items were measured on a 7-point Likert-type scale, ranging from "strongly disagree" (1) to "strongly agree" (7); higher scores indicate a higher level of product uniqueness relative to their major three competitors. The domestic growth opportunity scale, drawn from Burke (1984), measured market attractiveness. The Burke (1984) scale was modified in order to better capture the domestic market prospects specific to a retail industry. Five items were measured on a 7-point interval scale anchored by "very low" (1) and "very high" (7). Respondents were asked to indicate how they perceive the growth opportunities of their target market in the US domestic market considering future competition, short-term (3-year) market growth rate, long-term (10year) market growth rate, future profits, and "room" for growth in the domestic market in terms of retail sales and market share. Burke's (1984) scale has a Cronbach's alpha of 0.92.

To understand each firm's background, we solicited the following information: firms' average annual sales volume for the last 3 years, the number of domestic retail stores, the number of brands carried in its retail stores, the main product categories, the first entry mode, the first foreign market, and the continents where the firm operates.

An early draft of the survey instrument was reviewed by a group of business scholars with expertise in international research and by owners of SME retail businesses that were not included in the survey. They provided feedback on the clarity, comprehensiveness, face validity, and readability of the scales and survey instructions. Minor revisions were made in the wording of the questionnaire. All of the statistical analyses in this study were performed using PASW software, version 18. H1 was tested using a multiple regression analysis and $\mathrm{H} 2,3,4,5,6$, and 7 were tested using a binary logistic regression analysis.

\section{Results and discussion}

\section{Description of sample respondents}

Of the 76 participating firms, 32 (42.1\%) firms were founded between 1961 and 1990, and 26 (34.2\%) firms between 1991 and 2006. Approximately $29 \%$ of the respondents $(n=22)$ reported that their last three-year annual sales volume averaged less than $\$ 0.9$ million dollars. More than half of the participating firms own fewer than five domestic retail stores $(n=57,75 \%)$. In addition, a majority of the participating firms $(n=76$, $97.4 \%$ ) carries more than one brand in their retail store. As for the main product categories, less than half of retailers carry shoes $(n=40,52.6 \%)$, followed by women's clothing ( $n=36,47.4 \%)$ and women's accessories $(n=35,46 \%)$.

Of these 76 firms, 28 firms currently sell their products outside of the US market (i.e., international retailers). For the 28 international retailers, the first international market for 15 (53.6 \%) was Canada, followed by Mexico $(n=5,17.9 \%)$. This finding implies that Canada and Mexico might be the preferred countries to serve as the first foreign market for US SME apparel retailers because of their geographical and cultural proximity. For more than half of the international US apparel retailers in the sample, their first international sales were online $(n=16,57.1 \%)$, followed by exporting $(n=8,28.6 \%)$. None of the US-based apparel retailers in this sample utilized joint ventures when entering their first foreign market. This finding implies that for US apparel retailers, the Internet is a vital channel by which to reach foreign consumers. All of the internationalizing apparel retailers in this sample have entered the North American region, followed next by South America $(n=16,57.1 \%)$. 


\section{Evaluation of the measures}

To assess the dimensionality of each multi-item measure, a principal components analysis with Varimax rotation was performed. The following criteria were employed in examining the factors: (1) the recommended minimum of 0.40 or above was used to examine factor loadings; (2) factors had eigenvalues greater than 1.0; and (3) each factor needed to have more than a single item to increase its correlation with the attribute being measured. While the nine items measuring market knowledge were expected to represent two dimensions (foreign institutional knowledge and foreign business knowledge), the factor analysis produced one factor with a range of 0.691 to 0.931 and an average loading of 0.835 . As a result, an average of all nine items formed the final scale for market knowledge. The remaining multi-item measures (i.e., foreign networking, market commitment, product uniqueness, domestic growth opportunity) were also found to be uni-dimensional.

The reliability of each multi-item scale was assessed prior to subsequent analyses. The Cronbach alpha associated with the multi-item measures suggested generally high levels of reliability. With the exception of domestic growth opportunity, the reliability of all the measures exceeded the 0.70 level. While it was below the recommended cutoff value of 0.70 (Nunnally and Bernstein 1994), at 0.608, the reliability of domestic growth opportunity can be deemed acceptable for research (Nunnally 1967). The values of Cronbach's coefficients ranged from 0.941 (market knowledge) to 0.608 (domestic growth opportunity). To determine multicollinearity, analysis using Pearson's product movement correlations was performed among all variables in each analysis. Overall, the highest correlation was observed between market knowledge and foreign networking $(r=0.686)$, suggesting that potential multicollinearity, usually associated with a high correlation $(r>0.70)$ between independent variables, was not a problem.

\section{Hypotheses testing}

For $\mathrm{H} 1 \mathrm{a}$ and $\mathrm{1b}$, we anticipated that foreign sourcing experience and foreign networking are positive predictors of market knowledge. The beta coefficient for foreign sourcing experience was not significant $(\beta=-0.149, t=-1.665, p=0.100)$ while the beta coefficient for networking was positively significant $(\beta=0.734, t=8.186, p<0.001)$ (see Table 1). Therefore, H1a was not supported but H1b was accepted.

Hypotheses 2-6 were tested to determine the predictors of international market involvement (see Table 2). H2, which predicted that the older is, the higher its probability of international market involvement, is statistically supported by the data $(\beta=-0.069$., $p<0.01$ ), but the direction between firm age and international market involvement is directly opposite to what we anticipated. The odds ratio (OR) [confidence interval (CI) $95 \%$ ] between firm age and international market involvement is 0.934 (95 \% CI 0.8880.981), indicating that when firm age increased, the odds of the firm's international market involvement decreased by 0.934 times. H3 proposed that the higher a firm's foreign market knowledge, the greater its probability of international market involvement. A positive relationship was found $(\beta=1.737, p<0.01$ ), supporting H3. The results show that the odds ratio of market knowledge is 5.678 (95\% CI 1.997-16.145), indicating that when market knowledge increased, the odds of international market entry increased 5.678 times. In contrast to our expectations, H4, H5, and H6, hypothesizing 
Table 1 Results of the multiple regression predicting market knowledge

\begin{tabular}{llrrr}
\hline Independent variables & \multicolumn{4}{l}{ Multiple regression model } \\
\cline { 2 - 5 } & $\boldsymbol{b}$ (SE) & $\boldsymbol{\beta}$ & $\boldsymbol{t}$ value & $\boldsymbol{p}$ value \\
\hline Foreign sourcing experience & $-0.188(0.113)$ & -0.149 & -1.665 & 0.100 \\
Foreign networking & $0.606(0.074)$ & 0.734 & 8.186 & $0.000^{* * *}$ \\
Fvalue & $36.324^{* * *}$ & & & \\
Adjusted $R^{2}$ & 0.471 & & & \\
$R^{2}$ & 0.485 & & \\
\hline
\end{tabular}

$b$, unstandardized beta coefficients; $\mathrm{SE}$, standard error; $\beta$, standardized beta coefficients

*** $p<0.001$

Table 2 Results of the logistic regression predicting international market involvement

\begin{tabular}{llllll}
\hline Independent variables & \multicolumn{6}{l}{ Logistic regression model } \\
\cline { 2 - 6 } & $\boldsymbol{\beta}$ & SE & OR & $\mathbf{9 5} \% \mathbf{C l}$ & $\boldsymbol{p}$ value \\
\hline Firm age & -0.069 & 0.025 & 0.934 & $0.888-0.981$ & $0.007^{* *}$ \\
Market knowledge & 1.737 & 0.533 & 5.678 & $1.997-16.145$ & $0.001^{* *}$ \\
Market commitment & -0.195 & 0.331 & 0.823 & $0.430-1.574$ & 0.556 \\
Product uniqueness & -0.035 & 0.293 & 0.966 & $0.544-1.714$ & 0.906 \\
Domestic growth opportunity & -0.412 & 0.400 & 0.663 & $0.302-1.452$ & 0.304 \\
$X^{2}$ & $55.452^{* * *}$ & & & & \\
$d f$ & 5 & & & & \\
\% of correct prediction & 80.2 & & & & \\
Nagelkerke $R^{2}$ & 0.677 & & & & \\
\hline
\end{tabular}

OR, odds ratio

${ }^{*} p<0.05$; ${ }^{* *} p<0.01 ;{ }^{* * *} p<0.001$

the relationship between international market involvement and market commitment, product uniqueness, and domestic growth opportunity were not statistically supported.

For $\mathrm{H7a}$ and $7 \mathrm{~b}$, the mediating effect of market knowledge in the relationship between two sources of market knowledge (foreign sourcing experience and foreign networking) and international market involvement was tested using Baron and Kenny's (1986) definition of mediator. The lack of support for H1a ( $\beta=-0.149, t=-1.665, p=0.100)$ suggests that the relationship between foreign-sourcing experience and market knowledge does not satisfy the condition of mediating the role of market knowledge between foreign-sourcing experience and international market involvement, resulting in a failure to support H7a.

In contrast, given the support for $\mathrm{H} 1 \mathrm{~b}$ (foreign networking $\rightarrow$ market knowledge) and $\mathrm{H} 3$ (market knowledge $\rightarrow$ international market involvement), the direct relationship between foreign networking and international market involvement was tested, and the result was significant $(\beta=0.497, p<0.01)$. Market knowledge was significant after controlling for the foreign networking variable $(\beta=1.950, p<0.001)$ while foreign networking was no longer significant $(\beta=-0.361, p=0.213)$ (see Table 3 ). This result is evidence that market knowledge serves a mediating role in the relationship between foreign networking and international market involvement, supporting H7b. Table 4 shows a summary of $\mathrm{H} 1-\mathrm{H} 7$ testing. 
Table 3 Results of logistic regression for testing the mediating effect of market knowledge

\begin{tabular}{|c|c|c|c|c|c|c|c|c|c|c|}
\hline \multirow{2}{*}{$\begin{array}{l}\text { Independent } \\
\text { variables }\end{array}$} & \multicolumn{5}{|c|}{ Model 1} & \multicolumn{5}{|l|}{ Model 2} \\
\hline & $\beta$ & SE & OR & $95 \% \mathrm{Cl}$ & $p$ value & $\beta$ & SE & OR & $95 \% \mathrm{Cl}$ & $p$ value \\
\hline $\begin{array}{l}\text { Foreign } \\
\text { networking }\end{array}$ & 0.497 & 0.164 & 1.643 & $1.191-2.268$ & $0.003^{* *}$ & -0.361 & 0.290 & 0.697 & $0.395-1.230$ & 0.213 \\
\hline $\begin{array}{l}\text { Market } \\
\text { knowledge }\end{array}$ & & & & & & 1.950 & 0.465 & 7.025 & $2.825-17.470$ & $0.000^{* * *}$ \\
\hline$x^{2}$ & \multicolumn{5}{|c|}{$10.662^{* * *}$} & \multicolumn{5}{|c|}{$42.273^{* * *}$} \\
\hline$d f$ & \multicolumn{5}{|l|}{1} & \multicolumn{5}{|l|}{2} \\
\hline $\begin{array}{l}\text { \% of correct pre- } \\
\text { diction }\end{array}$ & \multicolumn{5}{|l|}{70.4} & \multicolumn{5}{|l|}{77.8} \\
\hline Nagelkerke $R^{2}$ & \multicolumn{5}{|l|}{0.168} & \multicolumn{5}{|l|}{0.555} \\
\hline
\end{tabular}

Dependent variable: international market involvement

${ }^{* *} p<0.01$; ${ }^{* * *} p<0.001$

Table 4 A Summary of H1-H7 testing

\begin{tabular}{lll}
\hline Proposed hypotheses & Findings \\
\hline H1a & Foreign sourcing experience $\rightarrow$ market knowledge & Not supported \\
$\mathrm{H} 1 \mathrm{~b}$ & Foreign networking $\rightarrow$ market knowledge & Supported \\
$\mathrm{H} 2$ & Firm age $\rightarrow$ international market involvement & Supported (opposite direction) \\
$\mathrm{H} 3$ & Market knowledge $\rightarrow$ international market involvement & Supported \\
$\mathrm{H} 4$ & Market commitment $\rightarrow$ international market involvement & Not supported \\
$\mathrm{H} 5$ & Product uniqueness $\rightarrow$ international market involvement & Not supported \\
$\mathrm{H} 6$ & Domestic growth opportunity $\rightarrow$ international market involvement & Not supported \\
$\mathrm{H} 7 \mathrm{a}$ & Foreign sourcing experience $\rightarrow$ market knowledge $\rightarrow$ international & Not supported \\
H7b & Foreign networking $\rightarrow$ market knowledge $\rightarrow$ international market & Supported \\
& involvement & \\
\hline
\end{tabular}

\section{Conclusion}

Overall, this study provides meaningful results that explain the factors related to the international expansion of SME apparel retailers in the US market. Conceptually guided by the literature on firm's internationalization and the Uppsala model, the research model was constructed in order to test the impact of two sources of learning (direct learning and indirect learning) on foreign market knowledge. In contrast to our expectations, foreign sourcing experience was not a significant predictor of the level of market knowledge for the sample SME apparel retailers. This result might stem from the US small apparel retailers' lack of interaction with sourcing producers. Factors including difficulties in communication, language barriers, and the number of producers scattered across the world may mean that a majority of SME apparel retailers work with independent agents (e.g., Li and Fung) to source apparel goods globally (Abernathy et al. 2006). Therefore, sourcing activities for SME apparel retailers may require less travel to sourcing countries and less interaction directly with local factory workers or consumers, resulting in few opportunities to learn about foreign markets. However, US SME apparel retailers' deeper and more numerous relationships with relatives, friends, former 
classmates, or former employers/employees in foreign countries are instrumental in knowing foreign markets, in categories such as local consumer cultures, tastes, needs, marketing, and commerce regulations. This result is consistent with prior research that found a noteworthy influence of foreign networking on obtaining foreign market knowledge (e.g., Ellis and Pecotich 2001; Musteen et al. 2010; Johnsen and Johnsen 1999; Prashantham 2006).

To understand the antecedents of international market involvement, we examined firm age, market knowledge, market commitment, product uniqueness, and domestic growth opportunity. The results in the relationship between firm age and international market involvement were unexpected: while a positive relationship between firm age and information market involvement was predicted, the younger apparel retailers showed a higher probability of international market involvement. Perhaps the high penetration of the Internet contributes to younger firms' international market involvement because this study shows the Internet as a major enabler of retailers' internationalization. This logic is also consistent with prior studies, which found e-commerce to be a primary facilitator of international sales for young retailers, based on limited organizational and financial resources (Foscht et al. 2006). In summary, young firms are not necessarily disadvantaged in international market involvement if they develop their own mechanisms by which to reach international consumers.

Following the logic of the Uppsala model, we investigated market knowledge and market commitment as antecedents of international market involvement. This study found that market knowledge is important in distinguishing SME apparel retailers that have international market involvement from those that do not. This finding confirmed the imperative role of market knowledge for foreign market involvement decisions in previous studies (e.g., Vida et al. 2000).

However, the finding of no relationship between market commitment and international market involvement was inconsistent with previous studies (e.g., Hadjikhani 1997). Perhaps the commitment of top-level apparel retail management to the time and effort necessary for international activities is not transferred to firms' actual behavior. One reason might lie in the size of firms in the study. For small retailers, the high investment demand may lessen their actual international market involvement regardless of their interests in international expansion. In summary, the results of $\mathrm{H} 3$ and $\mathrm{H} 4$ partially support the Uppsala model, which proposes the importance of market knowledge and market commitment to international market involvement decisions.

For H5, product uniqueness was tested to determine whether a retail-specific factor positively differentiates international and domestic apparel retailers. In contrast to our expectation, product uniqueness was not a major factor. This result is not consistent with the findings of previous studies (Moore and Burt 2007). First, small retailers may perceive that the uniqueness of the company brand and product range would be difficult to replicate in other markets (Hutchinson et al. 2009). Apparel retailing is a very handson, sensitive business; therefore, product uniqueness might not easily transfer to international markets for the small retailers in this study. Second, even though they have a unique product, small apparel retailers typically face a lack of the human and financial resources to undertake internationalization (Hutchinson et al. 2009). 
Domestic growth opportunity was not related to current international market involvement. This result is inconsistent with prior studies based on small and large European apparel retail firms (e.g., Lopez and Fan 2009; Wigley et al. 2005); however, this finding is consistent with prior research on large US retailers (e.g., Vida et al. 2000). This conflicting finding might be caused by the difference in land size between the US and European countries. The US is considerably bigger than Italy (32.6 times), Sweden (21.8 times), Spain (19.4 times), and France (15.3 times) (U.S. Central Intelligence Agency 2012). In a small European country, internationalization is a common strategic growth option (Autio et al. 2000) because of the limited growth potential in home markets. In the US, however, SME apparel retailers might seek future consumers primarily via domestic expansion before expanding internationally.

The mediating effect of market knowledge on the relationships between foreignsourcing experience (H7a), foreign networking $(\mathrm{H} 7 \mathrm{~b})$ and international market involvement was examined. The study found only a mediating effect of market knowledge on the relationship between foreign networking and international market involvement. In other words, foreign networking was not a direct prerequisite for SME apparel retailers' international market involvement. Instead, a greater level of foreign networking enables a firm to learn foreign consumers' preferences and needs, the market system, or commerce regulations, which in turn positively influences their international market involvement.

\section{Implications}

Academically, this study fills a gap in the research related to apparel retail firms' internationalization. The findings from previous studies on apparel retailers' internationalization are largely based on cases observation and focus primarily on European apparel firms (e.g., Guercini and Runfola 2010; Lopez and Fan 2009; Treadgold 1991; Wigley et al. 2005). Although the US apparel retail market exemplifies the long history of the apparel industry and includes representative global brands, very few studies so far have paid attention to US SME apparel retailers' internationalization. The study, therefore, addresses this gap by identifying and organizing important driving factors into a theoretical framework based on responses from US SME apparel retail firms. Ultimately, this research attempted to provide generalizability of the findings as to what extent firm-, retail-, and market-specific factors influence SME apparel retailers' international market involvement.

The Uppsala model has previously been applied to understand firms' international expansion in various sectors of industry, including IT products, general manufacturing goods, and automobile or industrial parts (e.g., Hashai and Almor 2004; Johanson and Vahlne 1990), but it has had limited application for the apparel retailing market. Considering this gap, adopting the Uppsala model makes a distinctive contribution to the literature on the apparel industry. The finding regarding the positive influence of foreign market knowledge on apparel retailers' international market involvement confirms the primary notion of the Uppsala model, which emphasizes knowledge for a firm's internationalization (e.g., Hashai and Almor 2004).

In addition, one drawback of the Uppsala model is that it places too much emphasis on experiential knowledge. The findings from previous studies have failed to explain 
whether diverse knowledge sources (e.g., experiential and indirect) contribute to building foreign market knowledge. This study addresses this gap by incorporating both hands-on and indirect sources for building foreign market knowledge. From this data, the study confirmed that foreign networking, rather than foreign sourcing experience, is a key factor in foreign market knowledge.

Another academic implication of this study is to highlight the mediation effect of market knowledge on the relationship between foreign networking and international market involvement. This finding provides direct evidence that informal and indirect learning from a foreign network benefits international market involvement for SME apparel retailers. In this regard, our results suggest one avenue worthy of further examination: how SME apparel retailers can sustain a wide, deep range of foreign networks to build foreign market knowledge.

Along with theoretical implications, the findings from this study hold crucial implications for marketers. Foreign market knowledge is a key factor of international market involvement for US SME apparel retailers and foreign network is a critical antecedent of foreign market knowledge among SME apparel retailers. For international expansion, it is highly advisable to promote acquisition of foreign market knowledge especially through foreign networks for SME apparel retailers. That is, founders or senior managers can benefit from their foreign networks and should therefore pay greater attention to the development of such networks. US SME apparel retailers should be guided to be aware of their international contacts as sources of important knowledge about foreign consumers' needs, foreign competition, cultural and legal differences, and different marketing systems. Top managers in the retail apparel industry should endeavor to establish contacts in diverse countries and strive to interact with them on a frequent basis.

Finally, the findings suggest that young firms can enter international markets and firm age may not be a barrier to internationalization. Specifically SME apparel retailers at an early stage of business can hire new manager experienced in international business or improve the internal planning procedures and capabilities of the firm related to international expansion. Moreover, US educators and policy makers should formulate programs to help US SME apparel retailers cultivate their competiveness regardless firm age, such as entrepreneurship and global vision and mind-set, which is in turn linked to international market involvement for SME apparel retailers.

\section{Limitations and suggestions for future research}

This study contains a few limitations that provide opportunities for future research. First, the results have been accomplished using a single segment of the SME retail industry, the apparel sector. Hence, caution should be noted in applying the results to other SME retail sectors (e.g., food or consumer electronics) because competencies and characteristics from products and services are different with the apparel industry. Related to this, further research may consider utilizing various service and/or product categories in order to generalize the findings. Second, approximately $65 \%$ of respondents in this study had not entered foreign markets. Many SME apparel retailers in the US seem to be reluctant to innovate and stay beyond the borders of domestic market. This fact suggests that future research should investigate barriers to SME retailers' willingness to expand. 
Authors' contributions

$\mathrm{HJC}$ and BJ carried out the molecular genetic studies, participated in the sequence alignment and drafted the manuscript. Both authors read and approved the final manuscript.

\section{Author details}

${ }^{1}$ Department of Human Environmental Studies, Southeast Missouri State University, One University Plaza, Mail Stop 5750, Cape Girardeau, MO 63701, USA. ${ }^{2}$ Department of Consumer, Apparel and Retail Studies, Bryan School of Business and Economics, The University of North Carolina at Greensboro, 212 Stone Building, Greensboro, NC 27402-6170, USA.

\section{Competing interests}

Both authors declare that they have no competing interests.

Received: 24 May 2015 Accepted: 16 September 2015

Published online: 05 November 2015

\section{References}

Abernathy, F. H., Volpe, A., \& Weil, D. (2006). The future of the apparel and textile industries: Prospects and choices for public and private actors. Environment and Planning A, 38, 2207-2232.

Alexander, N. (1990). Retailers and international markets: Motives for expansion. International Marketing Review, 7(4), 75-85.

American Apparel \& Footwear Association. (2009). An annual statistical analysis of the U.S. apparel \& footwear industries annual 2008 Edition (pp. 1-11). Arlington: American Apparel and Footwear Association.

Aspelund, A., \& Moen, O. (2005). Small international firms: Typology, performance, and implication. Management International Review, 45(3), 37-57.

Autio, E., Sapienza, H. J., \& Almeida, J. G. (2000). Effects of age at entry, knowledge intensity, and imitability on international growth. The Academy of Management Journal, 43(5), 909-924.

Baron, R. M., \& Kenny, D. A. (1986). The moderator-mediator variable distinction in social psychological research: Conceptual, strategic, and statistical consideration. Journal of Personality and Social Psychology, 51(6), 1173-1182.

Burke, M. C. (1984). Strategic choice and marketing managers: An examination of business-level. Journal of Marketing Research, 21(4), 345-359.

Chen, Y. F., \& Sternquist, B. (1995). Differences between international and domestic Japanese retailers. The Service Industries Journal, 15(4), 118-133.

Dillman, D. A., Smyth, J. D., \& Christian, L. M. (2009). Internet, mail, and mixed-mode surveys: The tailored design method (3rd ed.). New York: Wiley.

Ellis, P. D., \& Pecotich, A. (2001). Social factors influencing export initiation in small and medium-sized enterprises. Journal of Marketing Research, 38(1), 119-130.

Euromonitor. (2013). http://www.portal.euromonitor.com.libproxy.uncg.edu/Portal/Pages/Magazine/WelcomePage.aspx. Accessed 11 Nov 2014.

Evans, J., Bridson, K., Byrom, J., \& Medway, D. (2008a). Revising retail internationalization: Drivers, impediments and business strategy. International Journal of Retail \& Distribution Management, 36(4), 260-280.

Evans, J., Mavondo, F. T., \& Bridson, K. (2008b). Psychic distance: Antecedents, retail strategy implications, and performance outcomes. Journal of International Marketing, 16(2), 32-63.

Forsgren, M. (2002). The concept of learning in the Uppsala internationalization process model: A critical review. International Business Review, 11(1), 257-277.

Foscht, T., Swoboda, B., \& Morschett, D. (2006). Electronic commerce-based internationalization of small, niche-oriented retailing companies: The case of blue tomato and the snowboard industry. International Journal of Retail \& Distribution Management, 34(7), 556-572.

Gap Inc. (2015). Key facts. http://www.gapinc.com/content/gapinc/html/aboutus/keyfacts.html. Accessed 10 Sept 2015.

Guercini, S., \& Runfola, A. (2010). Business networks and retail internationalization: A case analysis in the fashion industry. Industrial Marketing Management, 39(6), 908-916.

Hadjikhani, A. (1997). A note on the criticisms against the internationalization process model. Management International Review, 2, 43-66.

Hadley, R. D., \& Wilson, H. I. M. (2003). The network model of internationalization and experiential knowledge. International Business Review, 12(6), 697-717.

Hashai, N., \& Almor, T. (2004). Gradually internationalizing 'born global'firms: An oxymoron? International Business Review, 13(4), 465-483.

Hutchinson, K., Fleck, E., \& Lloyd-Reason, L. (2009). An investigation into the initial barriers to internationalization: Evidence from small UK retailers. Journal of Small Business and Enterprise Development, 16(4), 544-568.

Hutchinson, K., Quinn, B., \& Alexander, N. (2006). SME retailer internationalization: Case study evidence from British retailers. International Marketing Review, 23(1), 25-53.

Jin, B. (2004). Achieving an optimal global versus domestic sourcing balance under demand uncertainty. International Journal of Operations and Production Management, 24(12), 1292-1305.

Jin, B., \& Jung, S. (2013). The role of social networks and global mindset of decision makers in SME firm internationalization. Paper presented at the 70th International Textile and Apparel Association, New Orleans, USA. http://cdm16001. contentdm.oclc.org/cdm/compoundobject/collection/p16001coll5/id/16778/rec/153. Accessed 30 Jan 2014.

Johanson, J., \& Vahlne, J.-E. (1977). The internationalization process of the firm: A model of knowledge development and increasing foreign market commitments. Journal of International Business Studies, 8(1), 23-32.

Johanson, J., \&Vahlne, J.-E. (1990). The mechanism of internationalization. International Marketing Review, 7(4), 11-24. 
Johanson, J., \& Wiedersheim-Paul, F. (1975). The internationalization of the firm: Four Swedish cases. Journal of Management Studies, 12(3), 305-322.

Johnsen, R. E., \& Johnsen, T. E. (1999). International market development through networks: The case of the Ayrshire knitwear sector. International Journal of Entrepreneurial Behaviour \& Research, 5(6), 297-312.

Johnson, M., \& Allen, B. (1994). Taking the English'apple' to Spain: The Adams experience. International Journal of Retail and Distribution Management, 22(7), 3-9.

Kapner, S. (2015). Gap to slash more stores, cut jobs. Wall Street Journal. http://www.wsj.com/articles/gap-plans-to-closestores-cut-jobs-1434399781. Accessed 18 Oct 2015.

Lee, M. (2010). Gap opens first China store, banks on rising incomes. http://www.reuters.com/article/2010/11/11/uk-gapchina-idUSLNE6AA04120101111. Accessed 12 Dec 2013.

Limited Brands. (2011). Annual Report 2010. http://www.limitedbrands.com/assets/Investors/4QYE2010_Financial_Presentation.pdf. Accessed 7 Jan 2015.

Lopez, C., \& Fan, Y. (2009). Interantionalisation of the Spanish fashion brand Zara. Journal of Fashion Marketing and Management, 13(2), 279-296.

Molla-Descals, A., Frasquet-Deltoro, M., \& Ruiz-Molina, M.-E. (2011). Internationalization patterns in fashion retail distribution: Implications for firm results. The Service Industries Journal, 31(12), 1979-1993.

Moore, C. M., \& Burt, S. (2007). Developing a research agenda for the internationalization of fashion retailing. In T. Hines \& M. Bruce (Eds.), Fashion marketing: Contemporary issues (pp. 48-65). Oxford: Butterworth-Heinemann.

Musteen, M., Francis, J., \& Datta, D. K. (2010). The influence of international networks on internationalization speed and performance: A study of Czech SMEs. Journal of World Business, 45, 197-205.

Navarro, A., Losada, F., Ruzo, E., \& Diez, J. A. (2010). Implications of perceived competitive advantages, adaptation of marketing tactics and export commitment on export performance. Journal of World Business, 45(1), 49-58.

Nunnally, J. C. (1967). Psychometric theory. New York: McGraw-Hill.

Nunnally, J. C., \& Bernstein, I. H. (1994). Psychometric theory (3rd ed.). New York: McGraw-Hill.

Oviatt, B., \& McDougall, P. (1994). Toward a theory of international new ventures. Journal of International Business Studies, $25(1), 45-64$.

Palmer, M., \& Quinn, B. (2005). An exploratory framework for analyzing international retail learning. International Review of Retail, Distribution and Consumer Research, 15(1), 27-52.

Prashantham, S. (2006). Foreign network relationships and the internationalization of small knowledge-intensive firms. International Journal of Entrepreneurship and Innovation Management, 6(6), 542-553.

Quinn, B., \& Doherty, A. M. (2000). Power and control in international retail franchising - Evidence from theory and practice. International Marketing Review, 17(4/5), 354-372.

Roach-Higgins, M. E., \& Eicher, J. B. (1992). Dress and identity. Clothing and Textiles Research Journal, 10(1), 1-8.

Rothaermel, F. T., Kotha, S., \& Steensma, H. K. (2006). International marketing entry by U.S. Internet firms: An empirical analysis of country risk, national culture, and market size. Journal of Management, 32(1), 56-82.

Stoll, E., \& Ha-Brookshire, J. (2012). Motivations for Success: Case of U.S. Textile and Apparel Small- and Medium-Sized Enterprises. Clothing and Textiles Research Journal, 30(2), 149-163.

The Associated Press. (2015). Wet Seal closing over 300 stores; Nearly 3,700 losing jobs. http://www.nytimes.com/aponline/2015/01/07/us/ap-us-wet-seal-store-closings.html. Accessed 7 Jan 2015.

Treadgold, A. (1991). Dixons and Laura Ashley: Different routes to international growth. International Journal of Retail \& Distribution Management, 19(4), 13-19.

U.S. Bureau of Economic Analysis. (2011). National income and product accounts table: Table 2.3.5. Personal consumption expenditures by major type of product. http://www.bea.gov/national/nipaweb2011/TableView.asp?SelectedTable= $65 \&$ ViewSeries $=$ NO\&Java $=$ no\&Request3Place $=$ N\&3Place $=$ N\&FromView $=$ YES\&Freq $=$ Year\&FirstYear $=1$ 1980\&LastYea $r=2010 \& 3$ Place $=$ N\&Update $=$ Update\&JavaBox $=$ no. Accessed 30 Oct 2014.

U.S. Central Intelligence Agency. (2012). https://www.cia.gov/library/publications/the-world-factbook/. Accessed 30 Oct 2014.

U.S. Small Business Administration. (2013). Small business profile: United States. http://archive.sba.gov/advo/research/ profiles/09us.pdf. Accessed 30 Oct 2014.

Vida, I., Reardon, J., \& Fairhurst, A. (2000). Determinants of international retail involvement: The case of large U.S. retail chains. Journal of International, 8(4), 37-60.

Wahba, P. (2015). J.Crew's Drexler bets on Madewell, outlets, and overseas to fix business. http://fortune.com/2015/03/19/ jcrew-madwell-outlets-overseas/. Accessed 18 Oct 2015.

Wigley, S. M., Moore, C. M., \& Birtwistle, G. (2005). Product and brand: Critical success factors in the internationalization of a fashion retailer. International Journal of Retail \& Distribution Management, 33(7), 531-544.

Williams, D. E. (1992). Retailer internationalization: An empirical inquiry. European Journal of Marketing, 26(8/9), 8-24. 